\title{
ANALISIS EFEKTIVITAS DAN EFEK SAMPING PENGGUNAAN CLOPIDOGREL TUNGGAL DAN KOMBINASI CLOPIDOGREL- ASPILET PADA PASIEN STROKE ISKEMIK DI RSUP DR.WAHIDIN SUDIROHUSODO MAKASSAR
}

\author{
Nurul Inayah, Marianti A. Manggau' ${ }^{1}$, Yunus Amran² \\ ${ }^{1}$ Fakultas Farmasi, Universitas Hasanuddin, Makassar \\ ${ }^{2}$ Fakultas Kedokteran, Universitas Hasanuddin, Makassar
}

Kata Kunci :

Clopidogrel, Aspilet, PT dan aPTT, Barthel Index, Gastrointestinal

\begin{abstract}
ABSTRAK
Aspilet dan Clopidogrel merupakan antiplatelet yang dapat digunakan tunggal maupun kombinasi, beberapa penelitian telah dilakukan dengan membandingkan efektivitas keduanya menunjukkan tidak ada perbedaan yang signifikan. Di Indonesia, belum pernah dilakukan penelitian mengenai manfaat dan efek samping penggunaan Clopidogrel tunggal maupun kombinasi Clopidogrel-Aspilet. Tujuan penelitian untuk mengetahui efektivitas penggunaan Clopidogrel tunggal dan kombinasi Clopidogrel-Aspilet untuk mencapai nilai normal Protrombin Time (PT) dan Activated Partial Thromboplastin Time (APTT) serta perbaikan klinis berdasarkan Barthel Index (BI) dan melihat efek samping penggunaan terapi terhadap gastrointestinal. Desain penelitian yang digunakan adalah penelitian observasional prospektif dan retrospektif. Jumlah sampel 26 pasien, terdiri dari penggunaan Clopidogrel tunggal (kelompok I) dan kombinasi Clopidogrel-Aspilet (kelompok II). Hasil pemeriksaan PT sebelum pemberian terapi, pada kelompok I $(9,46 \pm 0,518)$ dan kelompok II $(9,65 \pm 0,688)$ dengan nilai $\mathrm{p}=0,545$, nilai APTT pada kelompok I $(21,30 \pm 0,630)$ dan kelompok II $(21,53 \pm 1,198)$, nilai $p=0,920$. Setelah memperoleh terapi tampak bahwa perubahan nilai PT terhadap kelompok I $(11,38 \pm 1,120)$ dan kelompok II $(11,00 \pm 0,912)$ memperlihatkan tidak ada perbedaan bermakna diantara keduanya $(\mathrm{p}=0,396)$. Demikian juga nilai APTT terhadap kelompok I $(24,46 \pm 1,853)$ dan kelompok II $(23,61 \pm 2,063)$, nilai $(\mathrm{p}=0.186)$. Outcome klinis berdasarkan BI pada kelompok I dan II memberikan efek yang sama dengan nilai p sebelum pemberian 0,685 dan setelah pemberian $\mathrm{p}=0,297$. Berdasarkan kejadian efek samping pada kelompok I sebanyak 3 pasien $(23,1 \%)$ dan kelompok II sebanyak 10 pasien $(76,9 \%)$ mengalami nyeri ulu hati, dengan nilai $\mathrm{p}=0,006$. Dari penelitian yang telah dilakukan disimpulkan bahwa, penggunaan terapi Clopidogrel $75 \mathrm{mg}$ tablet tunggal lebih efektif dibandingkan dikombinasi dengan Aspilet $80 \mathrm{mg}$ chewable
\end{abstract}

\section{PENDAHULUAN}

Stroke adalah suatu penyakit yang terjadi saat aliran darah ke otak terputus. Tanpa oksigen dalam darah, sel otak akan mati (1). Setiap tahun, sekitar 795.000 orang mengalami stroke baru atau berulang. Sekitar 610.000 di antaranya adalah serangan pertama, dan 185.000 adalah serangan berulang. Pada tahun 2013, prevalensi stroke di seluruh dunia adalah 25,7 juta, dengan 10,3 juta orang mengalami stroke pertama. Penyebab kematian kedua setelah penyakit jantung pada tahun 2013, terhitung 11,8 persen dari total kematian di seluruh dunia disebabkan karena stroke(1). Sekitar 87\% stroke dikalsifikasikan sebagai stroke iskemik (2). Seperti stroke iskemik, penyebab utama stroke hemoragik adalah hipertensi yang tidak terkontrol (1).

Beberapa penelitian telah dilakukan dengan membandingkan efektivitas penggunaan Asetosal kombinasi Clopidogrel dan Asetosal tunggal menunjukkan tidak ada perbedaan yang signifikan, antara lain penelitian yang dilakukan oleh Charisma di Inggris (Clopidogrel and Aspirin versus Aspirin alone for the prevention of atherothrombotic events) menunjukkan bahwa kombinasi aspirin dan clopidogrel tidak lebih efektif daripada aspirin dalam menunjukkan kejadian stroke. Penelitian Chance (clopidogrel with aspirin in acute minor stroke or transient ischemic attack) dilakukan di Cina menunjukkan bahwa pemberian kombinasi aspirin-clopidogrel lebih efektif dalam mencegah stroke berulang dibandingkan dengan aspirin tunggal, namun tidak meningkatkan risiko pendarahan (3).

Penelitian lain menurut Bradford J. Woelke (Amerika Serikat), meta-analisis menunjukkan bahwa anti-platelet ganda (Aspirin-Clopidogrel) lebih unggul dari Aspirin saja, tapi tidak pada Clopidogrel saja, dan terapi anti-platelet ganda adalah lebih berbahaya daripada Clopidogrel saja (4). Selain itu, penelitian yang dilakukan oleh Titien dan Dewi di Yogyakarta (The Effectiveness Of Clopidogrel As An Antithrombotic Compared To Ticlopidine And Aspirin (Meta-Analysis), menunjukkan hasil bahwa penggunaan Clopidogrel lebih efektif dibanding dengan Aspirin, dan resiko terjadinya serangan iskemik dan perdarahan lebih rendah dibanding dengan Aspirin dan Ticlopidine (5).

Dari beberapa penelitian yang telah dilakukan, di Indonesia sendiri belum pernah dilakukan penelitian mengenai manfaat dan efek samping penggunaan Clopidogrel tunggal dibanding dengan penggunaan kombinasi ClopidogrelAsetosal, karena itulah penelitian ini dilakukan untuk melihat efektivitas dan efek samping dari 
penggunaan Clopidogrel tunggal dan penggunaan kombinasi Clopidogrel- Asetosal (Aspilet).

Tujuan penelitian ini adalah untuk mengetahui efektivitas penggunaan Clopidogrel tunggal dibanding dengan penggunaan kombinasi Clopidogrel-Aspilet mencapai nilai normal Protrombin Time (PT) dan Activated Partial Thromboplastin Time (aPTT). Untuk melihat efek samping penggunaan Clopidogrel tunggal dibanding dengan penggunaan kombinasi Clopidogrel-Aspilet terhadap gastrointestinal.

\section{METODE PENELITIAN}

\section{Rancangan Penelitian}

Penelitian ini merupakan penelitian observasional prospektif dan retrospektif, metode penelitian yang dilakukan adalah uji klinik dengan metode cohort.

\section{Lokasi dan Waktu Penelitian}

Penelitian ini dilakukan di Rumah Sakit Umum Pusat Dr. Wahidin Sudirohusodo Makaasar periode Februari-April 2018

\section{Bahan Penelitian}

Bahan yang digunakan adalah data rekam medik pasien (data laboratorium TP dan aPTT), lembar Barthel Index dan lembar kuesioner.

\section{Prosedur Kerja}

Pengumpulan data dilakukan dengan mencatat data-data yang ada di rekam medik penderita stroke iskemik yang menjalani rawat inap di Rumah Sakit Wahidin Sudirohusodo Makassar periode November 2017 - Januari 2018 kemudian lanjut menjalani rawat jalan Februari - April 2018. Data yang dikumpulkan adalah Umur, Jenis kelamin, Penyakit penyerta, serta Obat-obatan yang diberikan untuk pengobatan Stroke Iskemik.

\section{Analisi dan Penyajian Data}

Data yang diperoleh diolah dan dianalisis dengan "Program Analisis Statistik". Sebelum dilakukan analisis secara statistik terlebih dahulu dilakukan normalitas (Saphiro-Wilk) untuk mengetahui kenormalan distribusi dan untuk mengetahui uji statistik yang akan digunakan. Data penilaian efek terapi dan efek samping penggunaan Clopidogrel tunggal maupun kombinasi Clopidogrel-Aspilet tidak terditribusi normal sehingga : Analisis efektivitas terapi Clopidogrel tunggal maupun kombinasi dengan Aspilet dilakukan uji MannWhitney dan data efek samping penggunaan terapi Clopidogrel tunggal maupun kombinasi dengan Aspilet dilakukan uji Chi-Square.

\section{HASIL DAN PEMBAHASAN}

Subjek penelitian yang memenuhi kriteria inklusi dan eksklusi berjumlah 26 orang pasien. Subjek penelitian terdiri atas subjek laki-laki sebanyak 19 orang $(73,1 \%)$ dan perempuan sebanyak 7 orang (26,9\%). Karakteristik berdasarkan usia menunjukkan bahwa usia > 55 tahun ada 19 pasien $(73,1 \%)$ lebih banyak dari pada usia 40-55 tahun (7 pasien, 26,9\%). Menurut Kimbal (2009), faktor resiko pada pasien stroke iskemik adalah pasien stroke iskemik lebih banyak pada laki-laki dibanding perempuan serta usia (dua kali lipat setiap 10 tahun di atas usia 55)(6). Berdasarkan karakteristik pasien dengan kebiasaan merokok, ada 10 pasien $(38,5 \%)$ dengan riwayat kebiasaan merokok terkena stroke iskemik dan 16 pasien (61,5\%) tidak merokok terkena stroke iskemik. Hasil penelitian ini tidak sejalan dengan penelitian yang dilakukan oleh Palm et.al (2011) dan
Banerjee (2012) menyatakan bahwa adanya hubungan yang bermakna secara statistik antara riwayat merokok dengan kejadian stroke iskemik ( $p$ value $=0,001)$ dan $(p$ value $=0,09$ ). Merokok merupakan salah satu faktor risiko bagi kejadian stroke baik iskemik maupun hemoragik yang bisa dicegah. Dikatakan bahwa seperempat dari seluruh kejadian stroke di Amerika bisa dikaitkan dengan perilaku merokok. Perilaku merokok berasosiasi dengan hiperkoagulasi dalam tubuh, yang mengarah pada pembentukan trombus dan produksi plak. Hal ini bermula dari proses pembakaran produk rokok dan komponen penyusunannya yang membawa pada pembentukan tromboemboli yang kemudian mengalami translokasi ke bagian otak dan kemudian dapat menyebabkan terjadinya stroke $(7,8)$. Namun pada penelitian ini, pasien yang tidak merokok banyak yang mengalami penyakit Stroke Iskemik, hal ini di karenakan penyakit Stroke Iskemik bukan hanya di sebabkan oleh perilaku merokok melainkan ada beberapa faktor resiko lain yaitu penyakit Hipertensi dan Dislipidemia atau karena faktor makanan.

Penyakit komplikasi yang menyertai penyakit stroke iskemik dari semua subjek penelitian ini adalah penyakit dengan hipertensi (8 pasien, 30,8\%), penyakit dengan dislipidemia ada 4 pasien $(15,4 \%)$, penyakit dengan dislipidemia dan hipertensi terdapat 3 pasien $(11,5 \%)$, penyakit dengan hipertensi komplikasi dengan diabetes mellitus dan prostat terdapat 2 pasien $(7,7 \%)$. Berdasarkan tabel hasil tersebut dapat dilihat bahwa penyakit penyerta yang banyak terjadi pada pasien stroke iskemik adalah hipertensi dan penyakit dislipidemia, menurut Boehm.A.K, Esenwa.C and Elkind.M.S.V (2017) dan Kimbal K (2009), hipertensi dan hiperlidipidemia merupakan faktor resiko pada pasien stroke iskemik ${ }^{(6,9)}$.

\begin{tabular}{|c|c|c|c|}
\hline Variabel & & $\begin{array}{l}\text { Jumlah } \\
\text { Pasien (n) }\end{array}$ & Prosentase (\%) \\
\hline \multirow{2}{*}{ Jenis Kelamin } & Laki-Laki & 19 & 73,1 \\
\hline & Perempuan & 7 & 26,9 \\
\hline \multirow{2}{*}{ Usia (Tahun) } & $40-55$ & 7 & 26,9 \\
\hline & $>55$ & 19 & 73,1 \\
\hline \multirow{2}{*}{$\begin{array}{l}\text { Riwayat } \\
\text { Merokok }\end{array}$} & Ya & 10 & 38,5 \\
\hline & Tidak & 16 & 61,5 \\
\hline \multirow{12}{*}{$\begin{array}{l}\text { Penyakit } \\
\text { Penyerta }\end{array}$} & Dislipidemia & 4 & 15,4 \\
\hline & $\mathrm{DM}+\mathrm{HT}$ & 1 & 3,8 \\
\hline & HT & 8 & 30,8 \\
\hline & $\begin{array}{l}\text { DM + Dislipidemia } \\
+ \text { PJ }\end{array}$ & 1 & 3,8 \\
\hline & Dislipidemia + HT & 3 & 11,5 \\
\hline & $\mathrm{PJ}+\mathrm{HT}$ & 1 & 3,8 \\
\hline & HT + Alsheimer & 1 & 3,8 \\
\hline & $\mathrm{DM}$ & 1 & 3,8 \\
\hline & $\begin{array}{l}\text { Alzheimer + } \\
\text { Dislipidemia }\end{array}$ & 1 & 3,8 \\
\hline & $\mathrm{HT}+\mathrm{DM}+$ Prostat & 2 & 7,7 \\
\hline & $\begin{array}{l}\mathrm{HT}+\mathrm{DM}+ \\
\text { Dislipidemia }\end{array}$ & 1 & 3,8 \\
\hline & Epilepsis & 1 & 3,8 \\
\hline
\end{tabular}

Terapi tambahan yang paling banyak digunakan adalah Atorvastatin $20 \mathrm{mg}$ terdapat 17 pasien, Penelitian yang dilakukan oleh Amarence (2006), menyatakan bahwa penggunaan Atorvastatin dapat menurunkan risiko stroke dan kejadian koroner. Selain itu, uji coba SPARCL (Stroke Prevention by Aggressive Reduction in Cholesterol Levels) pada pencegahan stroke sekunder menunjukkan penurunan yang signifikan pada stroke berulang dengan Atorvastatin(10). Kemudian disusul pemberian Neurodex dan Citicolin 500 mg dimana masing-masing terdapat 15 pasien. Dalam beberapa tahun terakhir, beberapa uji klinis dilakukan untuk menemukan terapi citicolin yang efektif, tetapi tidak ada hasil 
yang meyakinkan yang diperoleh, setelah diperoleh hasil dalam uji coba ICTUS, kemanjuran citicoline dapat dipertanyakan, kasus pasien yang ditangani dengan Recombinant Tissue Plasminogen Activator (rtPA) dan citicolin, citicoline tidak dapat memberikan efek tambahan yang menguntungkan. Ini dapat dianggap sebagai standar untuk pengobatan stroke iskemik akut tetapi sangat berbeda dari praktik klinis yang sebenarnya. Hasil analisis efek citicoline pada pasien yang tidak diterapi dengan rtPA dan menerima dosis citicoline tertinggi dimulai dalam 24 jam pertama setelah onset, berdasarkan uji coba yang lebih baru tidak ada perbedaan yang signifikan, tinjauan ini mendukung beberapa manfaat citicoline dalam pengobatan stroke iskemik akut. Tetapi, pasien yang di terapi dengan (rtPA), citicoline memberikan manfaat terbatas(11), selanjutnya adalah pemberian Amlodipin sebanyak 14 pasien. Amlodipin merupakan golongan CCB tipe dihidropiridin yang menunjukkan efek menguntungkan terhadap outcome kardiovaskuler dan stroke pada kasus hipertensi (12).

Tabel 2. Data penggunaan obat tambahan lain selain penggunaan Clopidogrel $75 \mathrm{mg}$ dan Aspilet $80 \mathrm{mg}$

\begin{tabular}{|c|c|c|c|}
\hline \multirow{2}{*}{ Golongan Obat } & \multirow{2}{*}{ Jenis Obat } & \multicolumn{2}{|c|}{ Jumlah } \\
\hline & & $\mathrm{n}$ & $\%$ \\
\hline \multirow{6}{*}{ Vitamin/Suplemen } & Neurodex ${ }^{\circledast}$ & 15 & 14 \\
\hline & Vitamin C $100 \mathrm{mg}$ & 1 & 1 \\
\hline & Mecobalamin $500 \mathrm{mg}$ & 5 & 5 \\
\hline & Vitamin A $6000 \mathrm{IU}$ & 1 & 1 \\
\hline & Asam folat ${ }^{\circledast}$ & 1 & 1 \\
\hline & Citicolin $500 \mathrm{mg}$ & 15 & 14 \\
\hline \multirow{4}{*}{ Antihipertensi } & Diovan $^{\circledast}$ & 3 & 3 \\
\hline & Amlodipin & 14 & 13 \\
\hline & Furosemide $40 \mathrm{mg}$ & 2 & 2 \\
\hline & Hidroklortiazid $25 \mathrm{mg}$ & 1 & 1 \\
\hline Antihiperlipidemia & Atorvastatin $20 \mathrm{mg}$ & 17 & 16 \\
\hline \multirow{2}{*}{ Preparat Insulin } & Novorapid ${ }^{\circledR}$ & 1 & 1 \\
\hline & Lantus $^{\oplus}$ & 1 & 1 \\
\hline \multirow{2}{*}{ Antidiabetik Oral } & Gliquidone 30 mg & 1 & 1 \\
\hline & Metformin $500 \mathrm{mg}$ & 1 & 1 \\
\hline \multirow{2}{*}{ Antivertigo } & Betahistin $6 \mathrm{mg}$ & 2 & 2 \\
\hline & Flunarizin $5 \mathrm{mg}$ & 1 & 1 \\
\hline \multirow{2}{*}{ Antitukak } & Sucralfat sirup & 1 & 1 \\
\hline & Ranitidin $50 \mathrm{mg}$ & 4 & 4 \\
\hline Antidepresan & Amytriptilin & 2 & 2 \\
\hline \multirow{2}{*}{ Antikejang/Antiepilepsi } & Depakote 250 mg ${ }^{\oplus}$ & 1 & 1 \\
\hline & Phenytoin kaps & 1 & 1 \\
\hline Pengobatan Alzheimer & Aricept $^{\circledast}$ & 2 & 2 \\
\hline Preparat Tambah Darah & Sulfas Ferosus & 1 & 1 \\
\hline \multirow{2}{*}{ Antihistamin } & Cetirizine $10 \mathrm{mg}$ & 1 & 1 \\
\hline & Interhistin 50 mg ${ }^{\circledR}$ & 1 & 1 \\
\hline \multirow[t]{2}{*}{ Analgetik/Antipiretik } & Paracetamol $500 \mathrm{mg}$ & 1 & 1 \\
\hline & $\begin{array}{l}\text { Gabapentin (pereda } \\
\text { nyeri neuropati) }\end{array}$ & 5 & 5 \\
\hline Mineral & Zinc $20 \mathrm{mg}$ & 1 & 1 \\
\hline Antiplatelet lain & Cilostazole $100 \mathrm{mg}$ & 1 & 1 \\
\hline \multirow[t]{3}{*}{ Preparat Lainnya } & $\begin{array}{l}\text { (Paracetamol } 500 \mathrm{mg} \\
\text { + clobazam } 5 \mathrm{mg}+ \\
\text { amitriptilin } 1 / 3 \mathrm{tab} \text { ) } \\
\text { dalam kapsul }\end{array}$ & 1 & 1 \\
\hline & Levazide 100 mg ${ }^{\circledast}$ & 1 & 1 \\
\hline & Harnad D 0,2 mg ${ }^{\circledR}$ & 1 & 1 \\
\hline
\end{tabular}

Berdasarkan hasil penelitian, diperlihatkan hasil pemeriksaan PT sebelum pemberian terapi, pada kelompok I (Clopidogrel $75 \mathrm{mg}$ tablet tunggal) sebesar 9,46 $\pm 0,518$, selanjutnya pada kelompok II (kombinasi Clopidogrel 75 mg tablet dengan Aspilet $80 \mathrm{mg}$ chewable) adalah 9,65 \pm 0,688 dengan nilai $\mathrm{p}=0.545$. Hasil pemeriksaan APTT didapatkan pada kelompok I sebesar 21,30 $\pm 0,630$ selanjutnya pada kelompok II adalah 21,53 \pm 1,198 dengan nilai $\mathrm{p}=0,920$. Perbedaan rerata profil perdarahan terhadap semua kelompok berdasarkan pemeriksaan setelah memperoleh terapi, tampak bahwa perubahan nilai PT terhadap pemberian Clopidogrel $75 \mathrm{mg}$ tablet tunggal $(11,38 \pm 1,120)$, pemberian kombinasi Clopidogrel $75 \mathrm{mg}$ tablet dengan Aspilet $80 \mathrm{mg}$ chewable $(11,00 \pm 0,912)$ memperlihatkan tidak ada perbedaan bermakna diantara keduanya $(p=0,396)$. Demikian juga pada nilai APTT terhadap pemberian Clopidogrel $75 \mathrm{mg}$ tablet tunggal $(24,46 \pm 1,853)$, pada pemberian kombinasi Clopidogrel $75 \mathrm{mg}$ tablet Aspilet $80 \mathrm{mg}$ chewable $(23,61 \pm 2,063)$ keduanya juga tidak ada perbedaan yang bermakna $(\mathrm{p}=0,186)$, artinya penggunaan Clopidogrel tunggal maupun kombinasi dengan Aspirin tidak mempengaruhi nilai PT dan aPTT pada pasien stroke iskemik. Menurut penelitian yang dilakukan oleh Setyopranoto I et.al. (2013) menyatakan bahwa perubahan nilai PT terhadap pemberian aspirin $(12,29)$, Clopidogrel $(12,34)$ dan DLBS1033 $(12,12)$ memperlihatkan tidak ada perbedaan yang bermakna diantara ketiganya $(\mathrm{p}=0,709)$, perubahan nilai aPTT pada pemberian Aspirin $(29,81)$, Clopidogrel $(30,23)$ dan DLBS1033 $(30,10)$ juga memperlihatkan tidak ada pebedaan yang bermakna diantara ketiganya $(\mathrm{p}=0,990)$ (13).

Tabel 3. Perbandingan Nilai PT dan Nilai APTT pada penggunaan terapi Clopidogrel tunggal maupun terapi kombinasi ClopidogrelAspilet di RSUP dr. Wahidin Sudirohusodo Makassar bagian neurologi

\begin{tabular}{|c|c|c|c|}
\hline \multirow{2}{*}{$\begin{array}{c}\text { Data } \\
\text { Laboratorium }\end{array}$} & \multicolumn{2}{|c|}{$\begin{array}{l}\text { Nilai PT dan APTT } \\
\text { Mean } \pm \text { SD }\end{array}$} & \multirow[b]{2}{*}{$\mathbf{P}^{*}$} \\
\hline & $\begin{array}{c}\text { Kelompok I } \\
\text { (Clopidogrel } \\
\text { Tunggal) }\end{array}$ & $\begin{array}{c}\text { Kelompok II } \\
\text { (Clopidogrel- } \\
\text { Aspilet) }\end{array}$ & \\
\hline PT I & $1,31 \pm 0,480$ & $1,23 \pm 0,439$ & 0,762 \\
\hline PT II & $1,08 \pm 0,277$ & $1,00 \pm 0,000$ & 0,762 \\
\hline APTT I & $1,15 \pm 0,376$ & $1,15 \pm 0,376$ & 1,000 \\
\hline APTT II & $1,08 \pm 0,277$ & $1,00 \pm 0,000$ & 0,762 \\
\hline \multicolumn{4}{|c|}{${ }^{*}$ Uji Mann-whitney U test, $\mathrm{P}<0,05$ dinyatakan bermakna } \\
\hline $\begin{aligned} \text { Keterangan: } & \text { PTI }=n \\
& \text { PT II }=n i \\
& \text { APTTI }= \\
& \text { APTT II = }\end{aligned}$ & $\begin{array}{l}\text { T sebelum pember } \\
\text { T setelah pemberia } \\
\text { i APT sebelum pe } \\
\text { i APT setelah pem }\end{array}$ & $\begin{array}{l}\text { rapi } \\
\text { ai } \\
\text { ian terapi } \\
\text { n terapi }\end{array}$ & \\
\hline
\end{tabular}

Outcome klinis berdasarkan Barthel Index, diperlihatkan bahwa kondisi pasien kelompok I (Clopidogrel Tunggal), pada saat belum memperoleh terapi ada 2 pasien yang mengalami kondis berat, 8 pasien mengalami kondisi sedang dan hanya 3 pasien yang mengalami kondisi ringan. Sedangkan pada saat telah memperoleh terapi Clopidogrel tunggal ada 1 pasien yang mengalami kondisi sedang, 9 pasien mengalami kondisi ringan dan ada 3 pasien yang kondisinya sudah bisa melakukan aktifitas secara mandiri. Untuk kelompok II (Clopidogrel-Aspilet), saat belum memperoleh terapi ada 1 pasien yang mengalami kondis berat, 10 pasien mengalami kondisi sedang dan hanya 2 pasien yang mengalami kondisi ringan. Sedangkan pada saat telah memperoleh terapi kombinasi Clopidogrel-Aspilet tidak ada pasien yang mengalami kondisi sedang, 12 pasien mengalami kondisi ringan dan ada 1 pasien yang kondisinya sudah bisa melakukan aktifitas secara mandiri. Namun berdasarkan hasil statistik tidak ada perbedaan yang bermakna antara kedua kelompok dimana nilai $p=0,685$ (Barthel index saat belum memperoleh terapi) dan nilai $\mathrm{p}=0,297$ (Barthel index setelah memperoleh terapi), dimana nilai $\mathrm{p}>0,05$

Berdasarkan kejadian efek samping nyeri ulu hati pada kelompok I (Clopidogrel tunggal) sebanyak 3 pasien $(23,1 \%)$ yang mengalami nyeri ulu hati dan pada kelompok II (kombinasi Clopidogrel-Aspirin) sebanyak 10 pasien $(76,9 \%)$ dengan nilai $\mathrm{p}=0,006$. Berdasarkan hasil statistik terdapat perbedaan yang bermakna terhadap efek samping yang 
ditimbulkan antara penggunaan Clopidogrel tunggal dengan penggunaan kombinasi Clopidogrel-Aspirin dimana nilai $\mathrm{p}<0,05$. Menurut Kimbal et.al (2009), pasien yang menerima Aspirin lebih sering terkena distress GI atas, perdarahan intrakranial, dan perdarahan GI(6). Kerusakan GI yang disebabkan oleh penggunaan aspirin biasanya disebabkan oleh kombinasi efek epitel dan mikrovaskuler dengan sedikit atau tanpa peradangan. LDA (Low-dose Aspirin) menyebabkan GI mukosa dan efek sistemik dari deplesi prostaglandin melalui penghambatan siklooksigenase-1, prostaglandin memainkan peran penting dalam melindungi integritas lambung mukosa melalui peningkatan aliran darah lokal dan mempromosikan sintesis dan sekresi lendir dan bikarbonat. Dengan tidak adanya sintesis prostaglandin normal, lingkungan lambung menjadi lebih rentan terhadap eksogen (misalnya merokok) atau faktor endogen (H. Pylori, asam, pepsin, garam empedu) dan, akibatnya, lebih rentan untuk mengembangkan ulkus peptikum dan komplikasi perdarahan. Lingkungan asam menyebabkan aspirin tetap tidak terionisasi, memaksanya untuk berakumulasi dalam sel mukosa lambung, yang mengubah permeabilitas sel dan menyebabkan ulserasi (14).

Tabel 3. Outcome klinis berdasarkan Barthel index

\begin{tabular}{|c|c|c|c|c|c|}
\hline \multirow[t]{2}{*}{$\begin{array}{l}\text { Outcome Klinis } \\
\text { (Skore) }\end{array}$} & \multicolumn{2}{|c|}{$\begin{array}{c}\text { Kelompok I } \\
\text { (Clopidogrel } \\
\text { Tunggal) }\end{array}$} & \multicolumn{2}{|c|}{$\begin{array}{c}\text { Kelompok II } \\
\text { (Clopidogrel- } \\
\text { Aspilet) }\end{array}$} & $P$ \\
\hline & $\mathrm{n}$ & $\%$ & $n$ & $\%$ & \\
\hline
\end{tabular}

\begin{tabular}{|c|c|c|c|c|c|}
\hline \multicolumn{6}{|c|}{ Barthel Index I (sebelum pemberian terapi) } \\
\hline $12-19$ & 3 & 23,1 & 2 & 15,4 & \multirow{3}{*}{0,685} \\
\hline $9-11$ & 8 & 61,5 & 10 & 76,9 & \\
\hline $5-8$ & 2 & 15,4 & 1 & 7,7 & \\
\hline \multicolumn{6}{|c|}{ Barthel Index II (setelah pemberian terapi) } \\
\hline 20 & 3 & 23,1 & 1 & 7,7 & \multirow{3}{*}{0,297} \\
\hline $12-19$ & 9 & 69,2 & 12 & 92,3 & \\
\hline $9-11$ & 1 & 7,7 & 0 & 0 & \\
\hline \multicolumn{6}{|c|}{${ }^{*}$ Chi-Square Tests, $\mathrm{P}<0,05$ dinyatakan bermakna } \\
\hline \multicolumn{6}{|c|}{ Keterangan : $20 \quad$ : Mandiri } \\
\hline $12-19$ & \multicolumn{5}{|c|}{ : Ketergantungan Ringan } \\
\hline $9-11$ & \multicolumn{5}{|c|}{ : Ketergantungan Sedang } \\
\hline $5-8$ & \multicolumn{5}{|c|}{ ketergantungan Berat } \\
\hline $0-4$ & \multicolumn{5}{|c|}{ : Ketergantungan Total } \\
\hline
\end{tabular}

Faktor risiko utama untuk kejadian GI atas yang terkait dengan penggunaan aspirin termasuk riwayat ulkus peptikum atau ulkus perdarahan, penggunaan bersama OAINS lain atau antitrombotik, dan infeksi H. Pylori. Di antara faktor risiko untuk perdarahan ulkus terkait LDA, infeksi $\mathrm{H}$. Pylori adalah salah satu dari beberapa yang dapat diobati dan disembuhkan. Terapi kombinasi aspirin dengan terapi antiplatelet atau antikoagulan lainnya semakin umum dan mencakup terapi antiplatelet ganda pada pasien yang diobati dengan stent koroner atau setelah sindrom koroner akut, pada pasien dengan penyakit kardiovaskular yang sedang menjalani terapi antikoagulan untuk fibrilasi atrium, atau indikasi lainnya. Terapi antiplatelet ganda jelas telah menunjukkan peningkatan risiko pendarahan. Meta-analisis dan uji klinis acak telah menunjukkan bahwa, sementara efektif dalam manajemen penyakit kardiovaskular, terapi ganda dapat meningkatkan risiko kejadian perdarahan besar (14).

\section{KESIMPULAN}

Penggunaan antiplatelet pada pasien Stroke Iskemik sebaiknya diberikan yang tunggal saja (Clopidogrel tunggal), berdasarkan nilai PT, aPTT dan Barthel Index pada penggunaan antiplatelet Clopidogrel tunggal dibanding dengan penggunaan kombinasi Clopidogrel-Aspilet memberikan efektivitas yang sama, namun efek samping penggunaan terapi antiplatelet kombinasi ClopidogrelAspilet terhadap gastrointestinal lebih tinggi dari pada penggunaan Clopidogrel tunggal.

\section{DAFTAR PUSTAKA}

1. Benjamin EJ, Blaha MJ, Chiuve SE, Cushman M, Das SR, Deo R, de Ferrant SD, Floyd J, Fornage M, Gillespie C, Isasi CR, Jimenez MC, Jordan LC, Judd SE, Lackland D, Lichtman JH, Lisabeth L, Liu S, Longenecker CT, Mackey RH, Matsushita K, Mozaffarian D, Mussolino ME, Nasir K, Neumar RW, Palaniappan L, Pandey DK, Thiagarajan RR, Reeves MJ, Ritchey M, Rodriguez CJ, Roth GA, Rosamond WD, Sasson C, Towfighi A, Tsao CW, Turner MB, Virani SS, Voeks JH, Willey JZ, Wilkins JT, Wu JHY, Alger HM, Wong SS, Muntner P. 2017. Heart Disease andStroke Statistics 2017At-aGlance. American Stroke Association.

2. Mozzfarian. 2017. Stroke Fact Sheet. American Stroke Association.

3. Wang, Y., Wang, Y., Zhao, X., Liu, L., Wang, D. Wang, C., et al., Clopidogrel with Aspirin in Acute Minor Stroke or Transient Ischemic Attack. New England Journal of Medicine. 2013;

4. Woelke BJ, Angell D, Litow K. Clopidogrel alone is safer than clopidogre and aspirin for secondary prevention of acute ischemic stroke. Wayne State University School of Medicine: Amerika Serikat. 2017;

5. Siwi H, Titien Dan Dewi Setyaningsing. 2017. The Effectiveness of Clopidogrel as an Antithrombotic Compared To Ticlopidine And Aspirin (Meta-Analysis). Fakultas Farmasi Universitas Sanata Dharma, Kampus Iii Maguwoharjo Depok Sleman : Yogyakarta. doi: http://dx.doi.org/10.24071/jpsc.141565.

6. Koda - Kimble and young's. Applied Theraupetic the Clinical Use of Drugs tenth edition, Lippincott Williams \& Wilkins, awolterskluwer business two commerce square, 2009.

7. Palm, F, 2011. Etiology, Risk Factor and Sex Differences in Ischemic Stroke in the Ludwifshafen Stroke Study, a Populattion-Based Stroke Registry. Germany : Departement of Neurology, Stadisches Klinikum Ludwigshafen.

8. Banerjee, Sunip. 2012. Common Drug Interactions in Cardiology Prescription. Medicine Update. Vol. 22, Kolkata.

9. Boehm.A.K, Esenwa.C and Elkind.M.S.V. 2017. Stroke Risk Factors, Genetics, and Prevention. Circulation Research is published by the American Heart Association.

10. Hindy.G, Engstrom.G, Larsson.SC, Traylor.M, Markus HS, Melander 0 . 2018. Role of Blood Lipids in the Development of Ischemic Stroke and its Subtypes A Mendelian Randomization Study. Departement of Clinical Sciences in Malmo, Lund University.

11. Secades J.J; Sabin J.A; Castillo J; Tejedor E.D; Vila E.M; Rios J; Oudovenko N. 2016. Citicoline for Acute Ischemic Stroke: A Systematic Review and Formal Meta-Analysis of Randomized, Double-Blind, and PlaceboControlled Trials. National Stroke Association. Published by Elsevier. DOI:10.1016/j.jstrokecerebrovasdis.2016.04.010.

12. Weber, M.A., Ernesto L. Schiffrin, William B. White, Samuel Mann, Lars H. Lindholm, John G. Kenerson, John M. Flack, Barry L. Carter, Barry J. Materson, C. Venkata S. Ram, Debbie L. Cohen, Jean-Claude Cadet, Roger R. Jean-Charles, Sandra Taler, David Kountz, Raymond R. Townsend, John Chalmers, Agustin J. Ramirez, George L. Bakris, Jiguang Wang, Aletta E. Schutte, John D. Bisognano, Rhian M. Touyz, Dominic Sica, dan Stephen B. Harrap. Clinical Practice Guidelines for the Management of Hypertension in the Community: A Statement by the American Society of Hypertension and The International Society of Hypertension. The Journal of Clinical Hypertension. Vol 16 (1), 2014; hal. 14-26.

13. Setyopranoto I; Wijono D; Pudjiastono E.S; Wahyuningrum S; Indradewi A.S; Raymond R dan Tjandrawinata. Uji Klinik Buta Ganda Perbedaan Profil Perdarahan dan Outcome Klinis Pasien Stroke Iskemik dengan Pemberian DLBS1033, Aspirin, dan Clopidogrel. Bagian Neurologi Fakultas Kedokteran Universitas Gadjah Mada/SMF Saraf RSUP Dr.Sardjito Yogyakarta : Indonesia; 2013.

14. Cryer B, Mahaffey K.W. 2014. Gastrointestinal Ulcers, Role of Aspirin, And Clinical Outcomes: Pathobiology, Diagnosis, And Treatment. University of Texas Southwestern Medical School, Dallas, TX, Department of Medicine, Stanford University, Stanford, CA, USA. 